\title{
Effects of water physico-chemical parameters on tilapia (Oreochromis niloticus) growth in earthen ponds in Teso North Sub-County, Busia County
}

\author{
Agano J. Makori ${ }^{1}$, Paul O. Abuom , Raphael Kapiyo ${ }^{1}$, Douglas N. Anyona ${ }^{1}$ and Gabriel O. Dida ${ }^{2 *}$
}

\begin{abstract}
Small-scale fish farmers in developing countries are faced with challenges owing to their limited information on aquaculture management. Nile tilapia farmers in Teso North Sub-County recorded lower yields than expected in 2009 despite having been provided with required inputs. Water quality was suspected to be the key factor responsible for the low yields. This study sought to assess the effects of earthen pond water physico-chemical parameters on the growth of Nile tilapia in six earthen fish ponds under semi-intensive culture system in Teso North Sub-County. The study was longitudinal in nature with pond water and fish being the units of analysis. Systematic sampling was used to select five ponds while a control pond was purposively selected based on its previously high harvest. Four ponds were fed by surface flow and two by underground water. Each pond was fertilized and stocked with 900 fry of averagely $1.4 \mathrm{~g}$ and $4.4 \mathrm{~cm}$. Physico-chemical parameters were measured in-situ using a multi-parameter probe. Sixty fish samples were randomly obtained from each pond fortnightly for four months using a $10 \mathrm{~mm}$ mesh size and measured, weighed and returned into the pond. Mean range of physico-chemical parameters were: dissolved oxygen (DO) $4.86-10.53 \mathrm{mg} / \mathrm{l}$, temperature $24-26{ }^{\circ} \mathrm{C}, \mathrm{pH} 6.1-8.3$, conductivity $35-87 \mathrm{\mu S} / \mathrm{cm}$ and ammonia 0.01-0. $3 \mathrm{mg} / \mathrm{l}$. Temperature $(p=0.012)$ and conductivity $(p=0.0001)$ levels varied significantly between ponds. Overall Specific Growth Rate ranged between 1.8\% (0.1692 g/day) and 3.8\% (1.9 g/day). Ammonia, DO and pH in the ponds were within the optimal levels for growth of tilapia, while temperature and conductivity were below optimal levels. As temperature and DO increased, growth rate of tilapia increased. However, increase in conductivity, $\mathrm{pH}$ and ammonia decreased fish growth rate. Temperature and DO ranging between 27 and $30{ }^{\circ} \mathrm{C}$ and $5-23 \mathrm{mg} / \mathrm{l}$, respectively, and SGR of 3.8\%/day and above are recommended for higher productivity.
\end{abstract}

Keywords: Earthen fish ponds, Culture, Growth rate, Nile tilapia, Physico-chemical parameters

\section{Background}

Tilapia culture has been practised in more than 100 countries around the globe, yet most tilapia farmers, farm owners, farm managers, researchers, and graduate students in developing countries have little or lack accurate and critical information on tilapia culture (Abdel-Fattah, 2006). Lack of information on the basic requirements of an effective aquaculture system by small-scale fish farmers has handicapped the orderly, rapid development and high yield of the aquaculture

* Correspondence: gdidah@gmail.com

${ }^{2}$ School of Public Health, Maseno University, P. O. Box 333-40105, Maseno, Kenya Full list of author information is available at the end of the article industry in developing countries (Machena and Moehl, 2001). While the Sub-Saharan Africa region has numerous attributes such as underutilized land and water resources, cheap labor, high demand for fish and a favorable climate all year round, aquaculture production is still not at its maximum (Machena and Moehl, 2001). Optimal production of fish in culture systems has frequently been curtailed by several factors among them limited information on aquaculture set-up and poor information on pond water quality requirements for optimal fish production (Machena and Moehl, 2001).

Growth of fish is dependent on a wide range of positive or negative impacting factors. Studies show that 
growth of fish in aquaculture mainly depends on feed consumption and quality (Slawski et al., 2011); stocking density (Ma et al., 2006); biotic factors such as sex and age (Imsland and Jonassen, 2003); genetic variance; and abiotic factors such as water chemistry, temperature (Imsland et al., 2007), photoperiod (Imsland and Jonassen, 2003), and oxygen level (Bhatnagar and Devi, 2013). Therefore, successful management of fish ponds requires an understanding of water quality, which is determined by abiotic factors such as temperature, dissolved oxygen (DO), transparency, turbidity, water color, carbon dioxide, $\mathrm{pH}$, alkalinity, hardness, unionized ammonia, nitrite, nitrate, primary productivity, biological oxygen demand (BOD), plankton population among others (Bhatnagar and Devi, 2013). A study by Bryan et al. (2011) conducted in Pennsylvania in 1998 on 557 pond owners established that $10 \%$ of the respondents had experienced water quality problems in their ponds ranging from muddy water to toxicity leading to fish kills.

Concerns about pond water quality are directly related to its production and therefore water quality parameters of greatest concern to fish farming are important to consider in fish culture (Bryan et al., 2011). Therefore, when evaluating and selecting sites for earthen fish pond siting, the source of water and its quality are some of the main factors to consider while ensuring that the water source has a high concentration of dissolved oxygen and optimal temperatures which should be kept at the right levels throughout the culture period among other critical factors (Ngugi et al., 2007).

Studies show that a special set of water chemistry requirements, and optimal water quality is essential to a healthy, balanced, and functioning aquaculture system (DeLong et al., 2009). The growth of different fish species is also influenced by a different range of factors, among them water quality parameters. Fish growth is generally greater in ponds with optimal levels of DO, temperature among other parameters (Bartholomew, 2010), though different fish species have ideal levels of water quality parameters within which they grow optimally (Kausar and Salim, 2006). Nile tilapia (Oreochromis niloticus) is ideal for culture due to its high growth rates, adaptability to a wide range of environmental conditions, ability to grow and reproduce in captivity and ability to feed at low trophic levels (Abdel-Fattah, 2006). The most preferred temperature range for optimal growth of tilapia is 25 to $27^{\circ} \mathrm{C}$, while the ideal pH ranges between 6 and 9 (DeWalle et al., 2011).

In 2009, the government of Kenya through the ministry of fisheries development introduced Fish Farming Enterprise \& Productivity Programme (FFE \& PP) in 140 constituencies across the country. The principal aim was to enhance food security, generate income among the rural community and stimulate rural enterprise development.
In Teso North Sub-County, where the current study focused, 100 farmers benefited from the program at the time. Despite having been sensitized and supplied with adequate nutritious supplementary fish feeds and other crucial inputs essential for aquaculture, fish farmers in the selected constituencies still realized low yields from the semi-intensive aquaculture system. According to Ngugi et al. (2007), the expected yields from each pond at the stocking density of $3 \mathrm{fish} / \mathrm{m}^{2}$ for the mono-sex tilapia was $240 \mathrm{~kg}$ (8000 kg/ha/year).

However, 99 FFE \& PP ponds out of the 100 ponds within Teso North Sub-County recorded harvests below $150 \mathrm{~kg}$ with the lowest recording as low as $70 \mathrm{~kg}$, while the highest recorded $200 \mathrm{~kg}$. Some of the reasons attributed to low production include the quality of water that was reportedly not taken into consideration during the initial set-up stages (Abdel-Fattah, 2006). Such vital knowledge alongside other important information on culture conditions of the pond water, fish feeds, growth rates, stocking density, and expected yields was missing among small scale tilapia farmers in Teso North SubCounty, Busia County, Kenya. This study thus sought to generate accurate information on water-quality parameters required for optimal production of Nile tilapia by small scale farmers in Teso North Sub-County, Busia County, Kenya.

\section{Methods}

\section{Study area}

This study was carried out in Teso North Sub-County (Fig. 1) which covers $236.8 \mathrm{Km}^{2}$ in surface area with an estimated population of 117,947 (KNBS 2010). Teso North Sub-County has its main town located at Amagoro which lies at Latitude $0^{\circ} 37^{\prime} 40.335^{\prime} \mathrm{N}$ and Longitude $34^{\circ} 19^{\prime} 57.2736 \mathrm{E}$ at 1200 and $1500 \mathrm{~m}$ asl. The Sub-County is characterized by undulating terrain with highlands intersected by numerous valleys and two rivers namely: Malakisi and Malaba (Jaetzold et al, 2007). Most parts of the Sub-County receive mean annual precipitation of between 800 and $1700 \mathrm{~mm}$ (MoPND, 2008). Mean maximum temperatures range between 26 and $30{ }^{\circ} \mathrm{C}$ while the mean minimum temperature ranges between 14 and $22{ }^{\circ} \mathrm{C}$. A total of 184 households were engaged in fish farming at the time of the study (RoK, 2010). About 95\% of the farmers cultured tilapia in earthen fish ponds.

\section{Research design}

A longitudinal research design was adopted for this study in which measurements were done fortnightly for four months. A total of six earthen fish ponds were selected, five of them through systematic random sampling and one selected purposively to act as a control based on its high yields recorded during the previous harvesting 


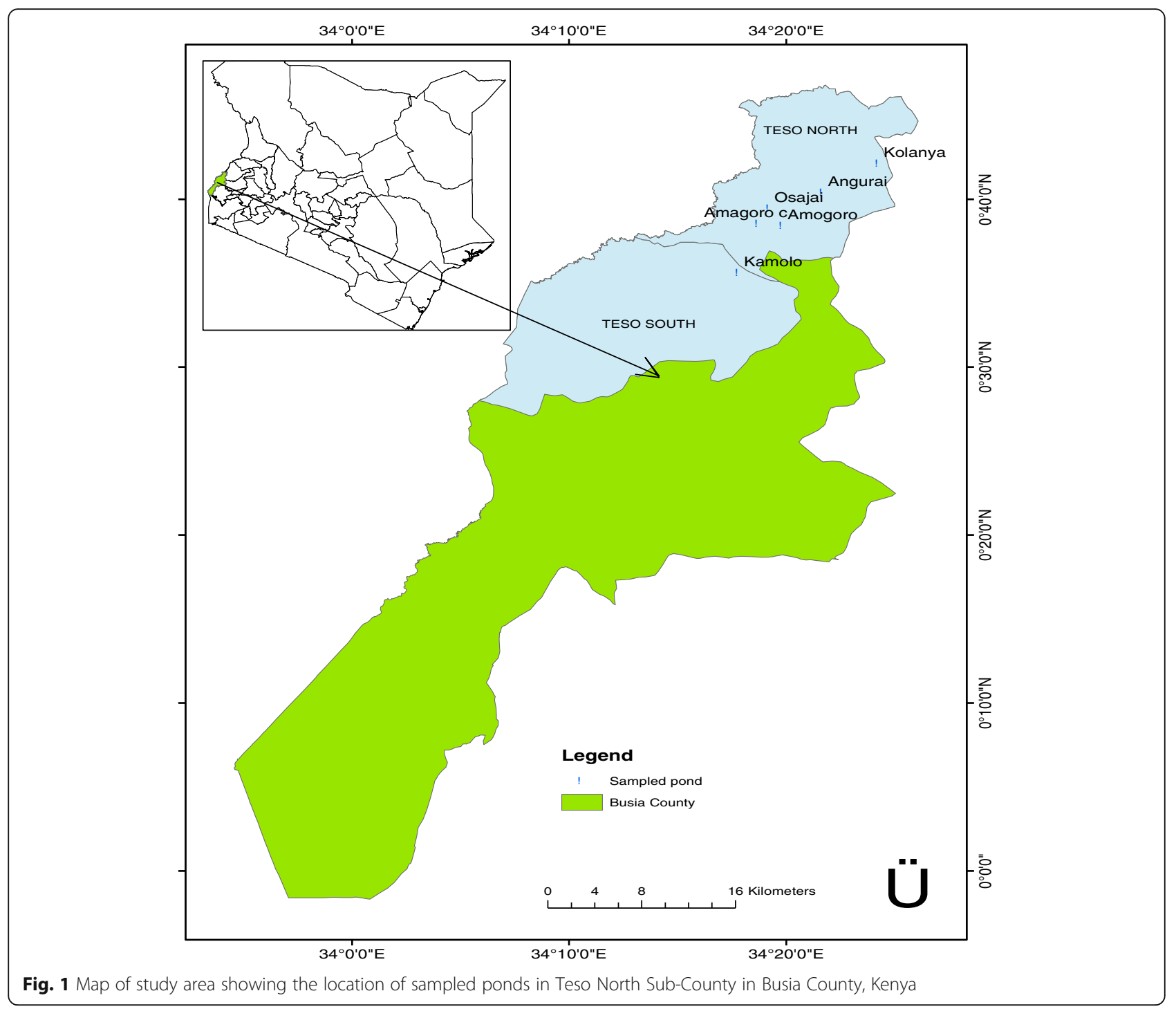

season. The fish ponds were classified into two classes based on the sources of their water supplies, i.e., well-surface flow ponds which comprised of Kamolo, Amagoro, and Osajai and underground spring-fed ponds comprising of Kolanya and Angurai. Each pond had an area of $300 \mathrm{~m}^{2}$ and an average depth of $1 \mathrm{~m}$.

\section{Ponds fertilization, stocking and feeding}

Each of the six ponds was initially fertilized 7 days prior to stocking, using organic manures from farm animals at a rate of $5 \mathrm{~kg} / 100 \mathrm{~m}^{2} /$ week (Ngugi et al., 2007). Male Nile tilapia fingerlings each weighing about $5 \mathrm{~g}$ and measuring about $0.4 \mathrm{~cm}$ total length were stocked at a stocking density of three fish per $\mathrm{m}^{2}$ in the six earthen ponds. Each pond was stocked with a total of 900 fingerlings. The culture system was semiintensive and expected production from each pond based on the preferred stocking density was $240 \mathrm{~kg}$
(Ngugi et al., 2007). The fish were fed twice a day (at 10:00 and 16:00) with the amount of feed being proportional to $10 \%$ body weight.

\section{Sampling}

Six sampling sites (two sites near the inlet, two in the middle, and two near the outlet) were identified within each fish pond. Fish growth (mean length and width) was conducted fortnightly alongside measurement of physico-chemical parameters for a period of 4 months. Sixty fish were randomly sampled from each earthen pond using a seine net of $10 \mathrm{~mm}$ mesh size. The fish samples were anesthetized using AQUI-S (a sedative and/or anesthetic that provides control in animal husbandry, fish transportation and research operations) at a dose of $2.5 \mathrm{~mL} / 100 \mathrm{~L}$ of water in a bucket prior to taking measurements to avoid stressing them. Their total lengths (TL) in centimeters and weights in grams were 
taken immediately using a fish measuring board and an electronic weighing scale, respectively. After the measurements, fish were transferred into a bucket containing clean water for stabilization before releasing them back to the pond. Specific Growth Rate (SGR) was calculated fortnightly for a period of 112 days. Specific growth rate refers to percentage increase in body dimensions per time and the results are given in percentage increase per day (Hopkins, 1992). The formula for calculating the SGR is as follows:

$$
\operatorname{SGR}(\% / \text { day })=\frac{\log \left(w_{t}\right)-\log \left(w_{i}\right)}{t} \times 100
$$

Where: wi is initial weight/length,

$w t$ is final weight/length,

$t$ is time in days.

A YSI multi-parameter probe (HI 9828 - YSI Incorporation, Yellow Spring, USA) was used to measure dissolved oxygen, temperature, $\mathrm{pH}$ and conductivity in situ. Total ammonia nitrogen (TAN) was also measured in situ using ammonia test kit (Model HI28049, Hach, USA). Each of the six ponds had recordings taken at the bottom, mid-water, and near the surface at 08:00, 10:00, 12:00, 14:00, 16:00 and 18:00 on different sampling days.

\section{Data analysis}

Descriptive statistics was used to outline the basic features of the data in the study by giving simple summaries like the mean and standard deviation of weight and length of fish and other physico-chemical parameters. Analysis of variance (ANOVA) was used to test the study hypotheses. The relationships between fish growth and physico-chemical parameters were determined using correlation and multiple regression analyses.

\section{Results and discussions}

\section{Physico-chemical parameters}

Dissolved oxygen levels measured in the six earthen fish ponds showed the highest $(10.6 \pm 8.4 \mathrm{mg} / \mathrm{L})$ levels to be in the control earthen pond and lowest $(4.9 \pm 2.8 \mathrm{mg} / \mathrm{L})$ levels at Osajai earthen pond, though the difference was not statistically significant $\left(F_{(5,53)}=1.72, p=0.1483\right)$ (Table 1).

The average dissolved oxygen (DO) levels in the six ponds ranged from $4.86 \mathrm{mg} / \mathrm{L}$ to $10.53 \mathrm{mg} / \mathrm{L}$ during the entire study period of 112 days with a mean of $7.066 \mathrm{mg} / \mathrm{L}$ (Table 2). According to Riche and Garling (2003), the preferred DO for optimum growth of tilapia is above $5 \mathrm{mg} / \mathrm{L}$. Other researchers have however proved that tilapia can tolerate condition of high oxygen super saturation of up to $40 \mathrm{mg} / \mathrm{L}$ (Tsadik and Kutty, 1987). On the lower limit, Ross (2002) noted that DO concentration of $3 \mathrm{mg} / \mathrm{L}$ should be the minimum for optimum growth of tilapia. Generally, fish growth and yields are greater in ponds with higher DO concentration (Bartholomew, 2010). In the current study, all ponds recorded minimum DO levels of less than $3 \mathrm{mg} / \mathrm{L}$ at certain times during sampling save for Angurai pond where the minimum DO concentration was $6.04 \mathrm{mg} / \mathrm{L}$. Dissolved oxygen levels were significantly different per growth period (days) $(\mathrm{F}=2.02, p=0.044)$, with highest $(9.29 \pm 4.22 \mathrm{mg} / \mathrm{L}) \mathrm{DO}$ levels recorded on day 0 and lowest $(5.33 \pm 3.83 \mathrm{mg} / \mathrm{L})$ on day 56 . The reduction in DO on day 56 could have been as a result of increased uptake by microorganisms during breakdown of accumulated organic matter in the pond. As regards diurnal oxygen variations at different sampling times, the findings showed different trends in each pond in relation to time of sampling, though the lowest DO levels were recorded at dawn across all the ponds. Consistent with the current study findings, Boyd (2010) also noted that in pond aquaculture, the lowest level of DO concentration is likely to occur at night.

Conductivity levels varied significantly between the six earthen ponds $\left(F_{(5,53)}=6.31, p=0.0001\right)$ with further analysis showing significantly lower conductivity levels at Amagoro compared to all the other ponds. The average conductivity in each of the six ponds ranged between $34.67 \mu \mathrm{S} / \mathrm{cm}$ and $86.67 \mu \mathrm{S} / \mathrm{cm}$. Diurnal mean conductivity between 08.00 and 16.00 at different ponds varied ranging from 24.32 to $99.42 \mu \mathrm{S} / \mathrm{cm}$ (Table 1). Conductivity levels also varied significantly at different durations (days) during sampling $\left(F_{(8,311),}=9.92\right.$, $p=0.0001)$, with highest conductivity $(83.81 \mu \mathrm{S} / \mathrm{cm})$ recorded on day 70 and lowest $(42.58 \mu \mathrm{S} / \mathrm{cm})$ on day 112 (Table 2).

Given that conductivity in aquatic ecosystems is mostly driven by soil composition or the bedrock on which a river flows (Russell et al., 2011), the varying conductivity levels observed in the six ponds could be attributed to the bedrock material on which the ponds were sited but could also be a result of human activities. Crane (2006) noted that conductivity values greater than $100 \mu \mathrm{S} / \mathrm{cm}$ were indicative of human activity. According to Russell et al. (2011), water conductivity of between 150 and $500 \mu \mathrm{S} / \mathrm{cm}$ is ideal for fish culture (Russell et al., 2011). Stone et al. (2013), however, put the desirable range of conductivity for fish ponds at between 100 and $2000 \mu \mathrm{S} / \mathrm{cm}$. It is therefore important to consider the rock type and soil composition of a site before construction of a fish pond.

$\mathrm{pH}$ levels showed a narrow range of variation between different fish ponds, with the highest $(6.76 \pm 0.31)$ mean $\mathrm{pH}$ recorded at Kamolo and the lowest $(6.32 \pm 0.15)$ at Amagoro. There were, however, no significant difference in $\mathrm{pH}$ between the six earthen ponds $(p=0.091)$ (Table $1) . \mathrm{pH}$ level differed significantly between sampling days 
Table 1 Mean physico-chemical parameters in the six earthen fish ponds

\begin{tabular}{|c|c|c|c|c|c|}
\hline Earthen Ponds & $\begin{array}{l}\text { Dissolved oxygen }(\mathrm{mg} / \mathrm{L}) \\
(\text { Mean } \pm \mathrm{SD})\end{array}$ & $\begin{array}{l}\mathrm{pH} \\
(\text { Mean } \pm \mathrm{SD})\end{array}$ & $\begin{array}{l}\text { Temperature } \\
\left({ }^{\circ} \mathrm{C}\right) \\
(\text { Mean } \pm \mathrm{SD})\end{array}$ & $\begin{array}{l}\text { Conductivity } \\
(\mu \mathrm{S} / \mathrm{cm}) \\
(\text { Mean } \pm \mathrm{SD})\end{array}$ & $\begin{array}{l}\text { Ammonia }(\mathrm{mg} / \mathrm{L}) \\
(\text { Mean } \pm \mathrm{SD})\end{array}$ \\
\hline Control & $10.6 \pm 8.4$ & $6.73 \pm 0.29$ & $26.49 \pm 2.41^{A}$ & $61.74 \pm 21.66^{B C}$ & $0.03 \pm 0.04$ \\
\hline Amagoro & $5.44 \pm 2.61$ & $6.32 \pm 0.15$ & $23.87 \pm 1.38^{B}$ & $34.52 \pm 21.1^{\mathrm{D}}$ & $0.07 \pm 0.16$ \\
\hline Angurai & $8.34 \pm 3.22$ & $6.71 \pm 0.28$ & $24.24 \pm 1.12^{B}$ & $60.63 \pm 29.5^{B C}$ & $0.02 \pm 0.02$ \\
\hline Kamolo & $6.45 \pm 4.86$ & $6.69 \pm 0.31$ & $23.66 \pm 0.88^{B}$ & $57.98 \pm 14.8^{C}$ & $0.01 \pm 0.01$ \\
\hline Kolanyo & $6.61 \pm 4.47$ & $6.76 \pm 0.67$ & $23.48 \pm 2.70^{B}$ & $81.52 \pm 10.1^{\mathrm{AB}}$ & $0.56 \pm 0.07$ \\
\hline Osajai & $4.86 \pm 2.81$ & $6.50 \pm 0.25$ & $24.55 \pm 1.69^{B}$ & $86.66 \pm 29.60^{A}$ & $0.03 \pm 0.02$ \\
\hline$F$-value & 1.72 & 2.03 & 3.31 & 6.31 & 0.75 \\
\hline$P$-value & 0.1483 & 0.091 & 0.012 & 0.0001 & 0.059 \\
\hline
\end{tabular}

Means with different supercripts in the same column are significantly different at $P<0.05$ (Data analyzed by Duncan's Multiple Range Test)

$\left(F_{(8311)}=4.86, p=0.0001\right)$ with the lowest $\mathrm{pH}(6.35)$ recorded on day 42 and highest (6.87) on day 70 (Table 2 ), while the mean daily $\mathrm{pH}$ between 08.00 and 16.00 fluctuated between 6.07 and 6.94 with only three ponds (Kolanya, Angurai, and Kamolo) having their $\mathrm{pH}$ ranging between 6.5 and 9; which is the ideal range for tilapia culture as reported by Bolorunduro and Abba (1996). Boyd (1998) noted that the daily fluctuations in $\mathrm{pH}$ result from changes in the rate of photosynthesis in response to daily photoperiod. As carbon dioxide accumulates in the water during the night, the $\mathrm{pH}$ falls. The process could be responsible for the low $\mathrm{pH}$ levels recorded in some of the ponds in this study. BEAR (1992) reported a pH range of between 6.5 and 9.0 as optimum for growth of tilapia. Crane (2006) reported that highly acidic water with $\mathrm{pH}$ less than 5.5 limited fish growth and reproduction, noting that the ideal $\mathrm{pH}$ range for freshwater aquaculture should range between 6.5 and 7.0, though a pH range of 6.1 to 8.0 is also considered satisfactory for the survival and reproduction of fish. Bryan et al. (2011) concurs that most fish would do better in ponds with a $\mathrm{pH}$ near 7.0 and that ponds with a $\mathrm{pH}$ less than 6.0 may result in stunting or reduced fish production.

Temperature levels differed significantly across the six earthen ponds $\left(F_{(5,53)}=3.31, p=0.012\right)$, with further analysis (DMRT) indicating a significantly higher mean temperature $\left(26.5 \pm 2.4{ }^{\circ} \mathrm{C}\right)$ at the control pond than all the other earthen ponds, whose levels ranged between 23.5 and $24.5{ }^{\circ} \mathrm{C}$ (Table 1). There were significant differences in temperature in relation to duration of study (days) $\left(F_{(8311)}=8.71, p=0.0001\right)$ whereby highest temperature $\left(25.67 \pm 2.53{ }^{\circ} \mathrm{C}\right)$, was recorded on day 98 , while the lowest $\left(22.99 \pm 1.63^{\circ} \mathrm{C}\right.$ ) was recorded on day 42 (Table 2). Temperatures between 20 and $36{ }^{\circ} \mathrm{C}$ have been reported by various researchers as being suitable for tilapia culture. According to Kausar and Salim (2006), for instance, the preferred temperature range for optimum tilapia growth in ponds is between 25 and $27{ }^{\circ} \mathrm{C}$. FAO (2011) reported the preferred temperature ranges of between 31 and $36{ }^{\circ} \mathrm{C}$, while Ngugi et al. (2007) gave a range of between 20 and $35{ }^{\circ} \mathrm{C}$ as ideal for tilapia culture. These previous studies are

Table 2 Mean physico-chemical parameters against duration of study (days)

\begin{tabular}{|c|c|c|c|c|c|}
\hline Period of study & $\begin{array}{l}\text { Dissolved oxygen (mg/L) } \\
\text { (Mean } \pm \text { SD) }\end{array}$ & $\begin{array}{l}\text { Temperature } \\
\left({ }^{\circ} \mathrm{C}\right) \\
(\text { Mean } \pm \mathrm{SD})\end{array}$ & $\begin{array}{l}\mathrm{pH} \\
(\text { Mean } \pm \mathrm{SD})\end{array}$ & $\begin{array}{l}\text { Conductivity } \\
(\mu \mathrm{S} / \mathrm{cm}) \\
(\text { Mean } \pm \mathrm{SD})\end{array}$ & $\begin{array}{l}\text { Ammonia }(\mathrm{mg} / \mathrm{L}) \\
\text { (Mean } \pm \mathrm{SD} \text { ) }\end{array}$ \\
\hline Day 0 & $9.29 \pm 4.22^{A}$ & $23.7 \pm 0.75^{B}$ & $6.79 \pm 0.38^{A}$ & $72.7 \pm 18.8^{A}$ & $0.02 \pm 0.01^{C D}$ \\
\hline Day 14 & $7.69 \pm 7.15^{\mathrm{AB}}$ & $25.1 \pm 2.93^{B}$ & $6.62 \pm 0.33^{A}$ & $44.3 \pm 34.2^{\mathrm{A}}$ & $0.01 \pm 0.01^{B}$ \\
\hline Day 28 & $6.30 \pm 2.97^{\mathrm{AB}}$ & $23.3 \pm 0.61^{B}$ & $6.46 \pm 0.40^{B C}$ & $76.4 \pm 28.1^{\mathrm{BC}}$ & $0.04 \pm 0.06^{\mathrm{D}}$ \\
\hline Day 42 & $6.93 \pm 5.34^{\mathrm{AB}}$ & $23.2 \pm 2.40^{\mathrm{B}}$ & $6.66 \pm 0.23^{B}$ & $57.3 \pm 26.1^{B}$ & $0.01 \pm 0.01^{B C}$ \\
\hline Day 56 & $6.99 \pm 4.30^{B}$ & $22.9 \pm 1.63^{\mathrm{A}}$ & $6.35 \pm 0.26^{\mathrm{A}}$ & $59.2 \pm 25.1^{\mathrm{A}}$ & $0.031 \pm 0.04^{\mathrm{CD}}$ \\
\hline Day 70 & $5.33 \pm 3.83^{B}$ & $25.0 \pm 3.01^{\mathrm{A}}$ & $6.53 \pm 0.46^{\mathrm{A}}$ & $73.3 \pm 12.4^{\mathrm{A}}$ & $0.01 \pm 0.02^{\mathrm{A}}$ \\
\hline Day 84 & $5.44 \pm 5.79^{\mathrm{AB}}$ & $25.6 \pm 2.43^{A}$ & $6.87 \pm 0.81^{B C}$ & $83.8 \pm 29.5^{B C}$ & $0.09 \pm 0.06^{\mathrm{CD}}$ \\
\hline Day 98 & $6.37 \pm 6.03^{\mathrm{A}}$ & $25.5 \pm 2.91^{\mathrm{A}}$ & $6.70 \pm 0.52^{\mathrm{D}}$ & $57.5 \pm 20.1^{\mathrm{D}}$ & $0.02 \pm 0.02^{\mathrm{CD}}$ \\
\hline Day 112 & $8.73 \pm 8.09^{\mathrm{AB}}$ & $25.7 \pm 2.53^{\mathrm{A}}$ & $6.68 \pm 0.21^{C D}$ & $42.6 \pm 36.9^{C D}$ & $0.01 \pm 0.05^{\mathrm{D}}$ \\
\hline F statistic & 2.02 & 8.71 & 4.86 & 9.92 & 18.0 \\
\hline$P$ value & 0.0437 & 0.0001 & 0.0001 & 0.0001 & 0.0001 \\
\hline
\end{tabular}

Means with different supercripts in the same column are significantly different at $P<0.05$ (Data analyzed by Duncan's Multiple Range Test) 
consistent with the current study findings in which the highest SGR of 4.4\%/day was recorded at a water temperature of $35^{\circ} \mathrm{C}$ in the control pond.

The mean ammonia levels in the six ponds ranged from $0.01-0.4 \mathrm{mg} / \mathrm{L}$ though the differences were not statistically significant $(p=0.59)$ (Table 1$)$. Ammonia levels were significantly different with respect to the period of study (days) $\left(F_{(8311)}=18, p=0.0001\right)$, with the lowest $(0.008 \mathrm{mg} / \mathrm{L})$ levels recorded on day 28 and highest $(0.086 \mathrm{mg} / \mathrm{L})$ on day 70 (Table 2$)$. According to TNAU, (2008), the optimal range of un-ionized ammonia is $0.02-0.05 \mathrm{mg} / \mathrm{L}$ in fish ponds. Consistent with this study, BFAR (1992) also reported ammonia levels of between $0.02-0.05 \mathrm{mg} / \mathrm{L}$ as the optimum for tilapia growth. Emerson et al. (1975), however, noted that a concentration of $0.6 \mathrm{mg} / \mathrm{L}$ of un-ionized ammonia, is capable of killing fish even if exposed briefly while chronic exposure to levels as low as $0.06 \mathrm{mg} / \mathrm{L}$ can cause gill and kidney damage and reduction in growth.

\section{Mean fish length and weight}

There was no significant difference in mean length and weight of fish obtained from the six earthen ponds ( $p=0.858$ and $p=0.42$, respectively). Nevertheless, fish obtained from the control earthen pond registered the highest mean length $(9.82 \pm 4.24 \mathrm{~cm})$ and weight $(31.03 \pm 28.5 \mathrm{~g})$ while Kolanya fish pond recorded the lowest mean length $(7.74 \pm 2.9 \mathrm{~cm})$ and Kamolo fish pond recorded the lowest mean weight $(17.1 \pm 11.95 \mathrm{~g})$ (Table 3). The growth of fish in total length was almost uniform increasing steadily from below $5 \mathrm{~cm}$ to over $12 \mathrm{~cm}$ on day 112 (Fig. 2). However, the highest mean total length was recorded in the control earthen pond and the least in Kolanya earthen pond (Table 3).

The control earthen fish pond recorded the highest mean fish weight $(31.03 \pm 28.5 \mathrm{~g})$ while Kamolo earthen fish pond recorded the lowest mean fish weight $(17.1 \pm 11.95 \mathrm{~g})$ (Table 3$)$. The difference in weight gain betweeen the control pond and Kamolo fish pond could be attributed to ideal conditions in the control fish pond,

Table 3 Mean length and weight of fish recorded in six ponds during the study period (112 days)

\begin{tabular}{lll}
\hline Earthen ponds & Mean length $(\mathrm{cm})$ & Mean weight $(\mathrm{g})$ \\
\hline Control & $9.82 \pm 4.24$ & $31.03 \pm 28.47$ \\
Amagoro & $8.46 \pm 2.99$ & $17.21 \pm 11.84$ \\
Angurai & $8.70 \pm 3.21$ & $18.05 \pm 12.79$ \\
Kamolo & $8.37 \pm 2.79$ & $17.13 \pm 11.95$ \\
Kolanyo & $7.74 \pm 2.91$ & $15.80 \pm 12.55$ \\
Osajai & $8.85 \pm 3.57$ & $20.98 \pm 17.10$ \\
F value & 0.38 & 1.01 \\
$P$ value & 0.858 & 0.423 \\
\hline
\end{tabular}

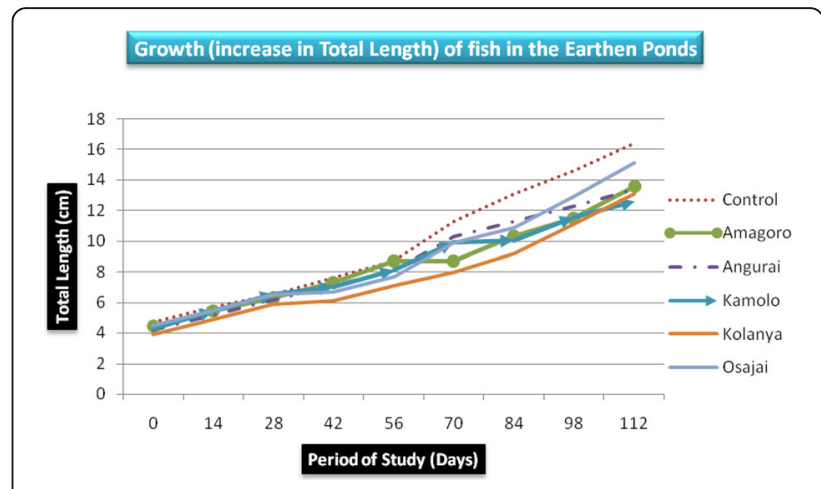

Fig. 2 Total Length of fish against time in days across the six earthen ponds

quality of water in the pond, feed availability, and stocking density, all of which may have favored the development of tilapia in the control pond (Ngugi et al., 2007). Further analysis of weight data collected on the 28th and 42nd day in Kolanya pond indicated a constant specific growth rate of $2.3 \%$ over the 14 days period, implying stunted growth of fish in this particular pond (Fig. 3).

\section{Specific growth rate (\%/day) and physico-chemical parameters}

The SGR attained at the end of the study (after 112 days), ranged from 3.7-4.4\%/day. The highest SGR of 4.4\%/day was attained in the control pond under the following water quality parameters: DO was $23.2 \mathrm{mg} / \mathrm{l}, \mathrm{pH}$ was 6.94, temperature was $30.25^{\circ} \mathrm{C}$, ammonia was $0.01 \mathrm{mg} / \mathrm{l}$ and conductivity was $23.5 \mu \mathrm{S} / \mathrm{cm}$. Given that the SGR was highest in the control pond corresponding to a DO of $23.2 \mathrm{mg} / \mathrm{l}$ (Fig. 4), it is clear that high DO levels influenced the growth of fish positively. Osajai pond recorded $4.0 \% /$ day SGR, while the other four earthen ponds all recorded the same growth rate of 3.7\%/day SGR (Table 4).

Dissolved oxygen affects the growth, survival, distribution, behavior, and physiology of fish and other aquatic organisms, and therefore oxygen depletion in water leads to poor feeding of fish, starvation, reduced growth, and more

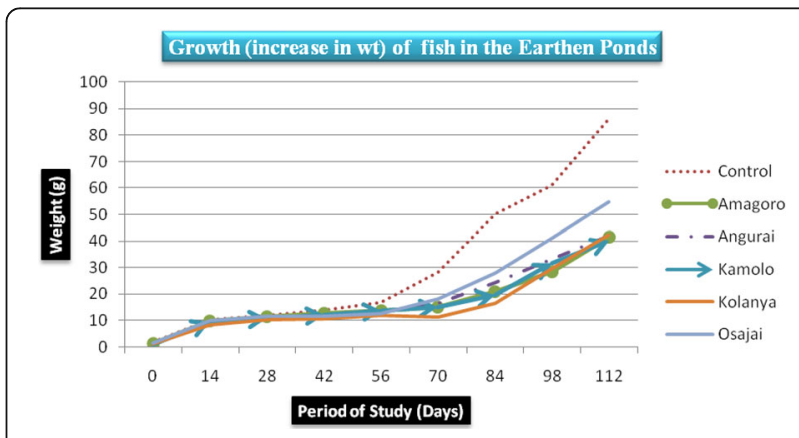

Fig. $3 \mathrm{~A}$ line graph showing the increase in weight with time across the six earthen ponds 


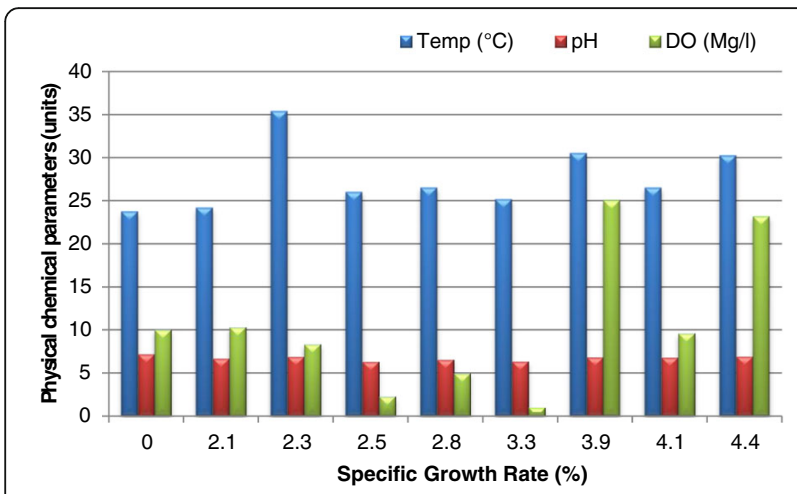

Fig. 4 Barchart showing variation of SGR with $\mathrm{DO}, \mathrm{pH}$ and temperature in the control pond

fish mortality, either directly or indirectly (Bhatnagar and Garg, 2000).

According to Bhatnagar and Singh (2010) and Bhatnagar et al. (2004) DO level > 5 ppm is essential to support good fish production. Bhatnagar et al. (2004) also suggests that DO levels of 1-3 ppm has sub lethal effect on growth and feed utilization, while DO levels of $0.3-0.8 \mathrm{ppm}$ is lethal to fishes. Ekubo and Abowei (2011) also cautioned that fish are likely to die if exposed to less than $0.3 \mathrm{mg} \mathrm{L}-1$ of DO for a long period of time. Avoiding excessive application of fertilizer or organic manure can help manage the levels of DO in fish ponds. Control of aquatic weeds and phytoplankton, as well as recycling of water and use of aerators can also be used by small-scale fish farmers to manage DO levels in earthen pond (Bhatnagar and Devi, 2013).

An increase in SGR was noted with a corresponding increase in temperature before falling sharply at a temperature of $35.53{ }^{\circ} \mathrm{C}$. The highest SGR of $4.4 \%$ /day was recorded at a temperature of $30.25{ }^{\circ} \mathrm{C}$ (Fig. 4). In the current study, the highest SGR was also obtained at a $\mathrm{pH}$ of 6.94 (near neutral) (Fig. 4), conductivity of $77.0 \mu \mathrm{S} / \mathrm{cm}$ (Fig. 5), and ammonia of $0.01 \mathrm{mg} / \mathrm{l}$ in the control pond. Consistent with the current study findings, Santhosh and Singh (2007) reported the suitable pH range for fish culture ranges between 6.7 and 9.5. Fish

Table 4 Percentage SGR of fish in six earthen ponds over the study period (112 days)

\begin{tabular}{lllllll}
\hline Days & Control & Amagoro & Angurai & Kamolo & Kolanya & Osajai \\
\hline 14 & 2.1 & 12.0 & 1.8 & 2.0 & 1.8 & 2.0 \\
28 & 2.3 & 2.3 & 2.4 & 2.3 & 2.3 & 2.3 \\
42 & 2.5 & 2.5 & 2.5 & 2.4 & 2.3 & 2.4 \\
56 & 2.8 & 2.6 & 2.6 & 2.6 & 2.5 & 2.5 \\
70 & 3.3 & 2.7 & 2.8 & 2.7 & 2.4 & 2.9 \\
84 & 3.9 & 3 & 3.2 & 3 & 2.8 & 3.3 \\
98 & 4.1 & 3.3 & 3.5 & 3.4 & 3.4 & 3.7 \\
112 & 4.4 & 3.7 & 3.7 & 3.7 & 3.7 & 4 \\
\hline
\end{tabular}

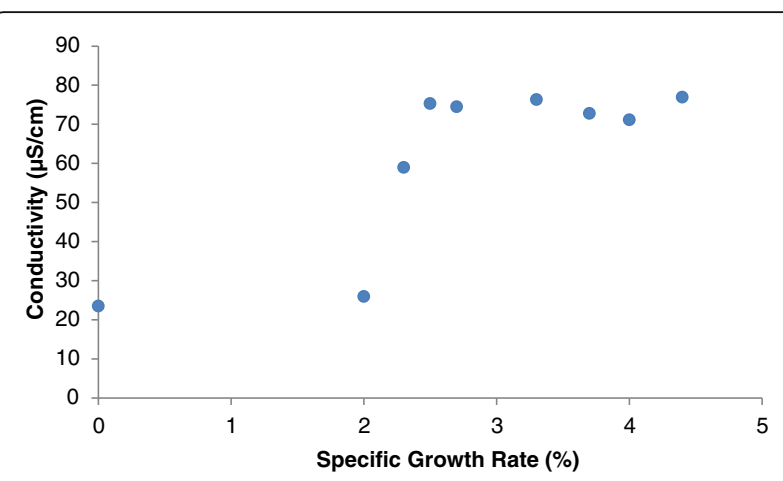

Fig. 5 A boxplot showing variation of SGR with conductivity in the control pond

have an average blood $\mathrm{pH}$ of 7.4, and therefore a little deviation from this value, generally between 7.0 to 8.5 is more optimum and conducive to fish life. However, fish can become stressed in water with a $\mathrm{pH}$ ranging from 4.0 to 6.5 and 9.0 to 11.0 and death is almost certain at a $\mathrm{pH}$ of less than 4.0 or greater than 11.0 (Ekubo and Abowei, 2011). High $\mathrm{pH}$ levels can be reduced by addition of gypsum or organic matter, while low $\mathrm{pH}$ levels can be rectified bu. application of quick lime (Bhatnagar and Devi, 2013).

Optimum conductivity for high fish production differs from one species to another. Stone and Thomforde (2004) recommended the desirable range 100-2000 $\mu \mathrm{S} /$ $\mathrm{cm}$ and acceptable range $30-5000 \mu \mathrm{S} / \mathrm{cm}$ for pond fish culture. The conductivity level of $77.0 \mu \mathrm{S} / \mathrm{cm}$ recorded in the control pond in the current study and which corresponded to the highest SGR was however slightly lower than the desirable range described by Stone and Thomforde (2004). Studies indicate that ammonia is a by-product from the metabolism of proteins excreted by fish and bacterial decomposition of organic matter like wasted food, feces, dead plankton among others (Bhatnagar and Devi, 2013). It has been observed that ammonia in the range $>0.1 \mathrm{mg} / \mathrm{L}$ tends to cause gill damage in fish, destroy mucous producing membranes, and cause sub-lethal effects like reduced growth, poor feed conversion, and reduced disease resistance (Bhatnagar and Devi, 2013).

Maximum limit of ammonia concentration for aquatic organisms is $0.1 \mathrm{mg} / \mathrm{L}$ (Santhosh and Singh, 2007), while Bhatnagar and Singh (2010) recommended that ammonia levels of $<0.2 \mathrm{mg} / \mathrm{l}$ are suitable for pond fishery. Consistent with these scholars, it was noted in the current study that the highest SGR for the control pond was registered at an ammonia level of $0.01 \mathrm{mg} / \mathrm{l}$, which was within the recommended $<0.2 \mathrm{mg} / \mathrm{l}$ ammonia for fish culture in ponds. Increasing pond aeration, regular water change, addition of quicklime are some of the ways that farmers can use in managing ammonia within 
their fish ponds (Bhatnagar and Devi, 2013). Given the specificity of certain parameters to the growth of fish, it is imperative to ensure that the various physicochemical parameters are at their optimal levels at all levels during the entire process of fish culture in ponds.

\section{Correlation between fish growth (weight and length) and physico-chemical parameters}

A strong positive correlation was observed between mean fish weight and: mean length $(r=0.92949, p=0.0001)$, temperature $(r=0.57488, p=0.0001)$, and dissolved oxygen $(r=0.30620, p=0.0243)$, while mean fish weight showed a negative correlation with conductivity $(r=-0.37$ 724, $p=0.0049$ ) (Table 5).

A positive correlation was also observed between mean fish length and temperature $(r=0.54232, \mathrm{p}=0.0001)$ and a negative correlation between mean fish length and conductivity $(r=-0.34323, p=0.0111)$. A fish pond with good water quality is likely to produce more and larger fish than a pond with poor water quality (Boyd, 1998). For instance, analysis of weight data collected on the 28th and 42nd day in Kolanya pond indicated a constant specific growth rate of $2.3 \%$ over the 14 days period, which was an indication of stunting of fish over that duration probably due to the effect of poor water quality.

An analysis of physico-chemical parameters during that period revealed that the mean dissolved oxygen and temperature levels during the same period ranged from $3.11-3.88 \mathrm{mg} / \mathrm{l}$ and $20.77-20.94{ }^{\circ} \mathrm{C}$, respectively. The levels of these two parameters could have been low for the optimal growth of tilapia in the Kolanyo earthen pond. In a different study, Abo-State et al. (2009), reported a SGR of between 3.308 and 3.513\%/day in tilapia fish cultured within a 70 day period under the following average values of water quality parameters: $\mathrm{DO}$ was $7.5 \mathrm{mg} / \mathrm{L}, \mathrm{pH}$ was 7.6 , temperature was $27.5{ }^{\circ} \mathrm{C}$, total ammonia nitrogen (TAN) was $0.040 \mathrm{mg} / \mathrm{L}$ (Abo-State et al., 2009). Mbugua (2008) reported that at stocking density of 2 fish $/ \mathrm{m}^{2}$, male tilapia can attain $200 \mathrm{~g}$ and above in 4 to 5 months. However in this study in which the stocking density was $3 \mathrm{fish} / \mathrm{m}^{2}$, the male tilapia in the six ponds attained mean weights ranging between $42.4 \pm 0.9 \mathrm{~g}$ and $86.1 \pm 1.3 \mathrm{~g}$.

According to USDA (1996), water quality in ponds changes continuously and this often affects the optimal levels of physical and biological characteristics. As was the case in the current study, high dissolved oxygen levels and high temperatures tend to favor the growth of fish in earthen ponds. Studies concur that most biological and chemical processes within fish ponds are influenced by temperature, hence the need to ensure that the temperatures are maintained at optimal levels and that the same temperature favor the optimal growth if the fish species reared.

\section{Regression between fish growth and physico-chemical parameters}

In the control pond, $99.9 \%$ of the variation in fish weight was explained by the five physico-chemical parameters, while that of the other five fish ponds ranged between 66.8 and $99.5 \%$. The multiple regression analysis generated different $R^{2}$ values for each of the six earthen ponds as indicated in Table 6.

Partial regression coefficient (B value) defines the direction and the magnitude of the slope of a regression line. In the current study, the B values associated with $\mathrm{pH}(-4.56)$ and conductivity $(-0.154)$ bore negative signs, implying that for every increase in one unit of $\mathrm{pH}$ and conductivity, the regression equation predicted a decrease of $4.56 \mathrm{~g}$ and $0.154 \mathrm{~g}$ of fish weight (dependent variable), respectively. The $B$ values associated with DO, temperature and ammonia bore positive signs, implying that for every increase of one unit of these parameters, there was a corresponding increase in fish weight by a certain unit. For instance, the regression equation

Table 5 Correlation matrix of fish length, weight and physic-chemical parameters

\begin{tabular}{|c|c|c|c|c|c|c|c|}
\hline & Dissolved oxygen & Temp & $\mathrm{pH}$ & Cond. & Ammonia & Mean length & Mean weight \\
\hline Dissolved oxygen & 1.0000 & & & & & & \\
\hline Temp & $\begin{array}{l}0.52790 \\
0.0001\end{array}$ & 1.0000 & & & & & \\
\hline $\mathrm{pH}$ & $\begin{array}{l}0.43224 \\
0.0011\end{array}$ & $\begin{array}{l}0.45172 \\
0.0006\end{array}$ & 1.0000 & & & & \\
\hline Cond. & $\begin{array}{l}-0.28925 \\
0.0339\end{array}$ & $\begin{array}{l}-0.20314 \\
0.1407\end{array}$ & $\begin{array}{l}0.02350 \\
0.8661\end{array}$ & 1.0000 & & & \\
\hline Ammonia & $\begin{array}{l}-0.15896 \\
0.2509\end{array}$ & $\begin{array}{l}0.17194 \\
0.2138\end{array}$ & $\begin{array}{l}-0.07659 \\
0.5820\end{array}$ & $\begin{array}{l}0.17190 \\
0.2139\end{array}$ & 1.0000 & & \\
\hline Mean length & $\begin{array}{l}0.12424 \\
0.3708\end{array}$ & $\begin{array}{l}0.54232 \\
0.0001\end{array}$ & $\begin{array}{l}0.08711 \\
0.5311\end{array}$ & $\begin{array}{l}-0.34323 \\
0.0111\end{array}$ & $\begin{array}{l}-0.04147 \\
0.7659\end{array}$ & 1.0000 & \\
\hline Mean weight & $\begin{array}{l}0.30620 \\
0.0243\end{array}$ & $\begin{array}{l}0.57488 \\
0.0001\end{array}$ & $\begin{array}{l}0.08139 \\
0.5589\end{array}$ & $\begin{array}{l}-0.37724 \\
0.0049\end{array}$ & $\begin{array}{l}-0.11036 \\
0.4269\end{array}$ & $\begin{array}{l}0.92949 \\
0.0001\end{array}$ & 1.0000 \\
\hline
\end{tabular}


Table 6 Coefficient of determination of the six ponds showing amount of variation in fish growth explained by physico-chemical parameters

\begin{tabular}{|c|c|c|c|c|c|c|c|c|c|}
\hline \multirow[t]{2}{*}{ Ponds } & \multirow[t]{2}{*}{$R$} & \multirow[t]{2}{*}{$R^{2}$} & \multirow{2}{*}{$\begin{array}{l}\text { Adjusted } \\
\text { R Square }\end{array}$} & \multirow{2}{*}{$\begin{array}{l}\text { Std. } \\
\text { Error of } \\
\text { the } \\
\text { Estimate }\end{array}$} & \multicolumn{5}{|c|}{ Change Statistics } \\
\hline & & & & & $\overline{R^{2}}$ & FChange & $\mathrm{df1}$ & $\mathrm{df} 2$ & Sig. F Change \\
\hline Control & $.999^{\mathrm{a}}$ & .999 & .997 & 1.54593 & .999 & 539.117 & 5 & 3 & .000 \\
\hline Amagoro & $.817^{\mathrm{a}}$ & .668 & .115 & 11.0730 & .668 & 1.208 & 5 & 3 & .476 \\
\hline Angurai & $.943^{\mathrm{a}}$ & .889 & .705 & 6.9885 & .889 & 4.823 & 5 & 3 & .113 \\
\hline Kamolo & $.865^{\mathrm{a}}$ & .749 & .330 & 9.80052 & .749 & 1.788 & 5 & 3 & .335 \\
\hline Kolanya & $.893^{\mathrm{a}}$ & .798 & .461 & 9.23804 & .798 & 2.366 & 5 & 3 & .255 \\
\hline Osajai & $.998^{\mathrm{a}}$ & .995 & .987 & 1.93360 & .995 & 124.704 & 5 & 3 & .001 \\
\hline
\end{tabular}

Predictors: (constant), ammonia, conductivity, pH, temperature, dissolved oxygen

predicted an increase of $2.409 \mathrm{~g}$ of fish weight with every increase of one unit of temperature.

\section{Conclusions}

In conclusion, dissolved oxygen, temperature and ammonia in the earthen ponds were within the optimum range for growth of tilapia, while conductivity and $\mathrm{pH}$ were not. The water used for culture of tilapia was slightly acidic. The control pond registered the highest growth of tilapia while the same differed in other fish ponds with stunted growth experienced in Kolanya fish pond between day 28 and 42 . The stunting was attributed to unfavorable temperatures that did not support the optimal growth of fish. Based on the findings therefore, it can be concluded that the low yields from the ESP fish ponds in 2010, was directly attributed to poor water quality in the earthen ponds, either because of lack of the right information or ignorance among the fish farmers.

Any changes to their environment add stress to the fish, and the larger and faster the changes, the greater the stress. It is therefore recommended that water of good quality as well as maintenance of all the other factors is very essential for ensuring maximum yield in a fish pond. This can only be achieved through sensitization and educating the fish farmers on comprehensive management of aquaculture systems.

Good water quality refers to that with adequate oxygen, proper temperature, transparency, limited levels of metabolites, and optimum levels of other environmental factors affecting fish culture. This information would enable the farmers to take better care of their fish ponds by frequently monitoring the conditions of the ponds, fish behavior, and water color for any abnormal changes.

\section{Abbreviations}

ANOVA: Analysis of variance; DO: Dissolved oxygen; GOK: Government of Kenya; NACOSTI: National Commission for Science, Technology and Innovation; SGR: Specific growth rate; TAN: total ammonia nitrogen

\section{Acknowledgements}

We wish to acknowledge the fish farmers from Teso North Sub-County, within Busia County for allowing us the use of their fish ponds for this study. The authors also thank the research assistants for their assistance throughout the study.

\section{Funding}

This study was financially supported by the National Commission for Science, Technology and Innovation (NACOSTI), Kenya, through Maseno University.

\section{Availability of data and materials}

All data sets generated during and/or analyzed during the current study is available from the authors on reasonable request.

\section{Authors' contributions}

PA, GD, RK and AM conceived and designed the study. DA, AM, and PA organized the field work. AM, PA, and DA collected the data. GD and DA performed the statistical analysis. AM, GD, and DA drafted the manuscript. All authors read and approved the final manuscript.

Ethics approval and consent to participate

Experimental protocols followed the guidelines approved by Maseno University Ethics Review Committee (ERC).

\section{Consent for publication}

Not applicable

\section{Competing interests}

The authors declare that they have no competing interests.

\section{Publisher's Note}

Springer Nature remains neutral with regard to jurisdictional claims in published maps and institutional affiliations.

\section{Author details}

${ }^{1}$ School of Environment and Earth Science, Maseno University, P. O. Box 333-40105, Maseno, Kenya. ${ }^{2}$ School of Public Health, Maseno University, P. O. Box 333-40105, Maseno, Kenya.

Received: 26 May 2017 Accepted: 23 October 2017

Published online: 15 November 2017

\section{References}

Abdel-Fattah ME. Tilapia Culture. 2006. (Available at: https://www.goodreads.com/ book/show/661835.Tilapia_Culture.) Accessed 22 July 2017.

Abo-State HA, Tahoun AM, Hammouda YA. Effects of Replacement of Soybean meal by DDGS combined with Commercial Phytase on Nile tilapia (Oreochromisniloticus) Fingerlings Growth Performance and Feed Utilization. 2009; Available at. http://www.idosi.org/aejaes/jaes5(4)/4.pdf.

Bartholomew WG. Effect of channel catfish stocking rate on yield and water quality in an intensive, mixed suspended-growth production system. 2010. 
Available at: http://afs.tandfonline.com/doi/abs/10.1577/A09-020.1\#. WfMAxxLg97k

BFAR. Basic biology of Tilapia. 1992. https://www.bfar.da.gov.ph/bfar/download/ nfftc/BasicBiologyofTilapia.pdf. Accessed 21 June 2017.

Bhatnagar A, Devi P. Water quality guidelines for the management of pond fish culture. Int J Environ Sci. 2013;3(6):1980-2009. https://doi.org/10.6088/ijes. 2013030600019.

Bhatnagar A, Garg SK. Causative factors of fish mortality in still water fish ponds under sub-tropical conditions. Aquaculture. 2000;1 (2):91-6.

Bhatnagar A, Jana SN, Garg SK, Patra BC, Singh G, Barman UK. Water quality management in aquaculture. In: Course manual of summerschool on development of sustainable aquaculture technology in fresh and saline waters, CCS Haryana agricultural, Hisar (India); 2004. p. 203-10.

Bhatnagar A, Singh G. Culture fisheries in village ponds: a multi-location study in Haryana, India. Agric Biol J N Am. 2010;1(5):961-8.

Bolorunduro PI, Abba YA. Water quality Management in Fish Culture 1996.

Boyd CE. Water quality for pond aquaculture. Res Develop. 1998;43:1-11.

Boyd CE. Dissolved oxygen concentration in pond aquaculture. 2010. Available at https://www.researchgate.net/publication/281309202_Dissolvedoxygen_ concentration_in_pond_aquaculture. Accessed 11 Aug 2017.

Bryan R, Soderberg W, Blanchet H, Sharpe WE. Management of Fish Ponds in Pennsylvania. 2011. Available at http://www.water-rresearch.net/Waterlibrary/ Lake/waterqualityponds.pdf. Accessed 28 Nov 2016.

Crane B. Results of Water quality Measurements in Messer Pond. 2006. Available at http://www.messerpond.org/Ecology/WaterSamplingSummary. pdf. Accessed 23 Aug 2017

DeLong DP, Losordo, TM, Rakocy JE. Tank culture of tilapia. Online; SRAC Publication No. 282. Southern Regional Aquaculture Center. 2009. Available at https://thefishsite.com/articles/tank-culture-of-tilapia

Dewalle DR, Swistock BR, Sharpe WE. Episodic flow - duration analysis: assessing toxic exposure of brook trout (Salvenius fontinalis) to episodic increases in aluminium. 2011. Available at: http://www.nrcresearchpress.com/doi/abs/10. 1139/f95-081\#.WfMIZBLg97k. Accessed 20 Aug 2017.

Ekubo AA, Abowei JFN. Review of some water quality management principles in culture fisheries. Res J Appl Sci Eng Technol. 2011;3(2):1342-57.

Emerson K, Russo RC, Lund RE, Thurston RV. Aqueous ammonia equilibrium calculations: effect of pH and temperature. J Fish Res Board Can. 1975; 32:2379-83.

FAO. Fisheries and Aquaculture Department. 2011. Available at http://www.fao. org/fishery/culturedspecies/Oreochromis_niloticus/en Accessed 29.08.2017.

Hopkins KD. Reporting fish growth, a review of the basics. Journal of World Aquaculture Society. 1992;23:173-9.

Imsland AK, Jonassen TM. Growth and age at first maturity in turbot and halibut reared under different photoperiods. Aquac Int. 2003;11:463-75.

Imsland AK, Schram E, Roth B, Schelvis-Smit R, Kloet K. Growth of juvenile turbot Scophthalmus maximus (Rafinesque) under a constant and switched temperature regime. Aquac Int. 2007;15:403-7.

Jaetzold R, Schmidt H, Hornetz B, Shisanya C. Farm Management Handbook of Kenya. Natural Conditions and Farm Management Information. Western Kenya. 2007;2(A) Available at: http://www.fao.org/fileadmin/user_upload/drought/ docs/FMHB\%20Nyanza\%20Province.pdf. Accessed 14 Dec 2016.

Kausar R, Salim M. Effect of Water Temperature on Growth Performance and Feed Conversion Ratio of Labeo rohita. 2006. http://www.oalib.com/paper/ 2147234\#.WfMKSRLg97k. Accessed 23 Apr 2017.

Kenya National Bureau of Statistics (KNBS) (2010). Population and Housing Census Results 2009, Minister of State for Planning, National Development and Vision 2030, Kenya.

Ma A, Chen C, Lei J, Chen S, Zhuang Z, Wang Y. Turbot Scophthalmus maximus: stocking density on growth, pigmentation and feed conversion. Chin J Oceanol Limnol. 2006;24:307-12.

Machena C, Moehl J. Sub-Saharan African aquaculture: regional summary. In Subasinghe RP, Bueno P, Phillips MJ, Hough C, McGladdery SE, Arthur JR. eds. Aquaculture in the Third Millennium. Technical Proceedings of the Conference on Aquaculture in the Third Millennium, Bangkok, Thailand, 2001; 341-355. NACA, Bangkok and FAO, Rome.

Mbugua HM. A Comparative Economic Evaluation of Fish Farming of three Important Aquaculture Species in Kenya. 2008. Available at: http://www. unuftp.is/static/fellows/document/henry07prfi.pdf. 23.07.2017.

Ministry of Planning and National Development (MoPND). Teso North District Development Plan (2008-2012). 2008.
Ngugi CC, James RB, Bethuel OO. A New Guide to Fish Farming in Kenya, Oregon State University, USA. 2007.

Republic of Kenya (2010). Fish Farming in Teso District, Ministry of Fisheries Development.

Riche M, Garling D. Fish: Feed and Nutrition. Feeding Tilapia in Intensive Recirculating Systems. 2003. Available at; http://www.hatcheryfeed.com/ hf-articles/141\%. Accessed 13 May 2017.

Ross LL. Environmental physiology and energetic. Fish and Fisheries Series. 2002; 25:89-128. Accessed at http://link.springer.com/chapter/10.1007\%2F978-94011-4008-9_4 Accessed on 14 Sept 2013.

Russell M, Shuke R, Samantha S. Effects of Conductivity on Survivorship and Weight of Goldfish (Carassius auratus). 2011. Available at http://departments. juniata.edu/biology/eco/documents/Russell_et al.pdf. 23 Apr 2017.

Santhosh B, Singh NP. Guidelines for water quality management for fish culture in Tripura, ICAR Research Complex for NEH Region, Tripura Center, Publication no.29. 2007.

Slawski H, Adem H, Tressel RP, Wysujack K, Kotzamanis Y, Schulz C. Austausch von Fischmehl durch Rapsproteinkonzentrat in Futtermitteln für Steinbutt (Psetta maxima L). Züchtungskunde. 2011;83:451-60.

Stone N, Shelton JL, Haggard BE, Thomforde HK. Interpretation of Water Analysis Reports for Fish Culture. Southern Regional Aquaculture Center (SRAC) Publication No. 4606. 12 pg. 2013.

Stone NM, and Thomforde HK. Understanding Your Fish Pond Water Analysis Report. Cooperative Extension Program, University of Arkansas at Pine Bluff Aquaculture / Fisheries. 2004.

Tamil Nadu Agricultural University (TNAU). Water quality Management. Accessed at http://www.agritech.tnau.ac.in/fishery/fish_water.html. 2008. Accessed 19 Aug 2017.

Tsadik GG, Kutty MN. Influence of ambient temperature and dissolved oxygen on feeding and growth of the tilapia (Oreochromis niloticus) 1987. (www.fao.org/ docrep/field/003/AC168E/AC168E00.htm).

USDA US. Department of Agriculture. Aquaculture outlook. 1996;4:26 - 28.

\section{Submit your next manuscript to BioMed Central and we will help you at every step:}

- We accept pre-submission inquiries

- Our selector tool helps you to find the most relevant journal

- We provide round the clock customer support

- Convenient online submission

- Thorough peer review

- Inclusion in PubMed and all major indexing services

- Maximum visibility for your research

Submit your manuscript at www.biomedcentral.com/submit
C) Biomed Central 